\title{
KESADARAN DAN PERSEPSI USAHA MIKRO DAN KECIL TERHADAP CROWDFUNDING SYARIAH
}

\author{
${ }^{1}$ Rahmawati Apriliani, ${ }^{2}$ Anju Ayunda, ${ }^{3}$ Sarrah Fitriani Fathurochman \\ Kajian Timur Tengah dan Islam, Universitas Indonesia \\ Jalan Salemba Raya 4 Jakarta 10430, Indonesia \\ irhaapriliani@gmail.com
}

\begin{abstract}
Abstrak
Penelitian ini bertujuan untuk menganalisa kesadaran dan persepsi Usaha Mikro dan Kecil di JABODETABEK terhadap pembiayaan permodalan usaha dengan konsep crowdfunding syariah. Metode yang digunakan dalam penelitian ini adalah deskriptif kuantitatif. Hasil penelitian menunjukkan bahwa secara umum kesadaran UMK terhadap pembiayaan crowdfunding baik konvensional maupun syariah masih rendah. Namun persepsi yang cukup baik dan UMK responden berpotensi untuk menggunakan crowdfunding syariah sebagai permodalan usaha di masa depan.
\end{abstract}

Kata Kunci: Crowdfunding, Crowdfunding Syariah, Usaha Mikro dan Kecil (UMK).

\section{Abstract}

This study aims to analyze awareness and perceived of Micro and Small Business in JABODETABEK area on the financing for business capital in Islamic crowdfunding concept. Research method used in this study is descriptive quantitative. The results shows that in general, MSE has a low awareness of crowfunding financing both in conventional and Islamic scheme. However, the level of perceived showed by MSE is quite well and the respondents have the potential to use Islamic crowdfunding as their capital business in the future.

Kata Kunci: Crowdfunding, Islamic Crowdfunding Syariah, Micro and Small Enterprise (MSE).

\section{PENDAHULUAN}

Usaha Mikro Kecil dan Menengah (UMKM) memiliki kontribusi yang sangat besar bagi laju pertumbuhan ekonomi Indonesia. Kontribusi yang disumbangkan UMKM antara lain perannya sebagai penyedia lapangan kerja sehingga turut menjadi instrument pengurangan pengangguran dan melalui kegiatan produksi, UMK dapat menambah nilai pendapatan nasional. Sayangnya, dalam upaya UMKM untuk turut membangun perekonomian bangsa, UMKM juga menghadapi banyak kendala sehingga sulit untuk berkembang. 
Rahmawati R, Anju A, Sarrah F. Kesadaran dan Persepsi Usaha..

Badan Pusat Statistik (BPS) pada tahun 2018 mempublikasikan gambaran umum mengenai seberapa besar UMKM telah memberikan sumbangsihnya kepada Negara sekaligus gambaran detail mengenai permasalahan yang dihadapi oleh UMKM. Tercatat sampai dengan tahun 2016 sebanyak 26.073.689 Usaha Mikro Kecil (UMK) mampu membuka lapangan kerja bagi 59.266.885 orang. Jumlah ini jauh lebih besar dibandingkan dengan Usaha Menengah Besar (UMB) sebesar 348.567 unit usaha yang hanya mampu menyerap tenaga kerja sebanyak 19.406.401 orang.

Seperti yang telah disebutkan sebelumnya, besaran angka-angka ini

\section{Grafik 1}

\section{Persentase UMK yang Menyatakan Adanya Kendala Usaha (Persen)}

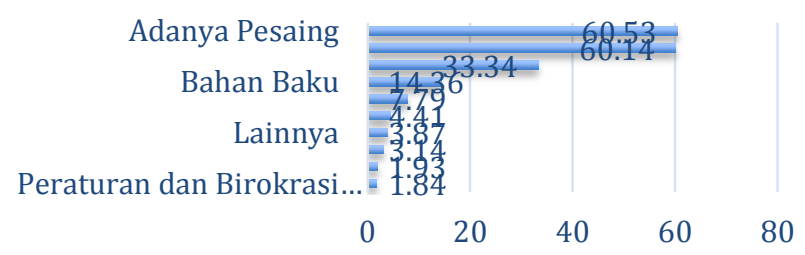

Sumber: Sensus Ekonomi 2016, BPS (2018).

Fakta terkait permodalan yang menjadi kendala UMK ini menjadi sebuah kondisi paradoks di negeri ini. Hal ini seperti yang disampaikan oleh (Rosengard dan juga diiringi oleh besarnya kendala yang menghalangi berkembangnya para UMKM. Kendala perihal akses permodalan menjadi kedua terbesar bagi UMK setelah kendala akibat munculnya banyak pesaing yaitu sebesar 60,14\% (BPS, 2018). Padahal, permodalan merupakan faktor produksi yang utama yang harus terpenuhi dalam proses produksi atau usaha. Meskipun saat ini banyak lembaga keuangan yang menyediakan fasilitas permodalan, namun hanya sekitar $12 \%$ pelaku usaha yang mengajukan atau memperoleh pinjaman kredit tersebut. Survei BPS tersebut dapat dilihat pada grafik 1 berikut ini. 
lembaga keuangan lain jusru tidak mampu memenuhinya karena prosedur dan syarat yang menyulitkan.

Melejitnya perkembangan teknologi yang begitu cepat termasuk di bidang keuangan atau yang biasa disebut dengan Financial Technology (FinTech). FinTech turut membawa solusi bagi akses permodalan untuk pelaku usaha. Salah satunya yaitu apa yang dikenal dengan crowdfunding. Crowdfunding menjadi ramai perbincangan dalam satu dekade terakhir di hampir seluruh dunia.Crowdfunding dapat menjadi output dari pengadopsian teknologi informasi dan komunikasi yang memiliki kemampuan untuk mengatasi tantangan keuangan dalam kewirausahaan. Tantangan tersebut antara lain memberikan peluang penyediaan akses modal bagi usaha kecil, membuka akses ekspor, serta mempercepat aliran modal dalam masyarakat tanpa harus terhalang oleh jarak (World Bank, 2013).

\section{Di Indonesia crowdfunding} tumbuh cepat dengan munculnya platform-platform yang dibuat oleh anak bangsa. Berdasarkan The $3^{\text {rd }}$
Asia Pacific Region Alternative Finance Industry Report 2018 oleh CCAF (Cambridge Centre for Alternative Finance), kategori $\mathrm{P} 2 \mathrm{P} /$ Marketplace Business Lending jauh lebih besar peningkatannya dengan kategori pendanaan alternatif online lainnya. Pada tahun 2016, pangsa pasarnya sebesar $\$ 21,65$ juta dan meningkat hingga lebih dari dua kali lipat pada tahun 2017 dengan nilai $\$ 53,47$ juta. Hal ini diperkirakan karena para pemilik bisnis mulai melirik sumber pendanaan lain.

Hal ini dibuktikan dengan penelitian yang dilakukan oleh (Asaba et al., 2016) bahwa UMKM di Indonesia selain perihal keuangan, kendala lain yang terkait yaitu mengenai skema penyaluran dana dari pemerintah. Dalam hal ini, fintech berpotensi untuk membantu menyelesaikan masalah-masalah ini yaitu platform pinjaman alternatif seperti Peer to Peer (P2P) Lending ataupun crowdfunding. Studi oleh (Ibrahim dan Verliyantina, 2012) juga menyatakan bahwa terbatasnya akses permodalan atau rendahnya inklusi keuangan UMKM di 
Rahmawati R, Anju A, Sarrah F. Kesadaran dan Persepsi Usaha..

Indonesia sangat mungkin untuk diselesaikan oleh model investasi seperti crowdfunding syariah utamanya untuk membiayai proyekproyek baru dengan akad mudharabah.

Penelitian ini berusaha untuk menelusuri kesadaran dan persepsi pelaku UMK terhadap model crowdfunding syariah. Hal ini dianggap penting untuk mengurangi inklusi keuangan, membantu menyelesaikan masalah permodalan, serta pentingnya pengetahuan UMK atas fintech yang semakin berkembang.

Sehingga, crowdfunding yang muncul saat ini tidak hanya sebatas hadir di kalangan UMK, namun dapat dimanfaatkan dengan sebaikbaiknya. Penelitian ini juga untuk membuktikan studi-studi teoritis mengenai crowdfunding syariah khususnya melalui perspektif UMKM.

\section{TINJAUAN TEORI}

\section{Crowdfunding}

(Achsien dan Purnamasari, 2016) menyebutkan definisi crowdfunding dari beberapa ahli. Antara lain,
(Arolas dan Guevara, 2012) menjelaskan crowdfunding dalam konsep mendanai proyek tertentu sebagai kesempatan untuk usaha kecil maupun para pengusaha menuju kesuksesan.(Massolution, 2012), (Belleflameet al., 2011) serta (Wheat et al., 2013), mendefinisikannya secara umum yaitu sebagai sebuah praktik penggalangan dana atau investasi dengan memanfaatkan situs atau website sehingga dapat menarik perhatian masyarakat. Praktik ini juga dapat digunakan sebagai pembiayaan berbagai macam usaha baik oleh investor kecil maupun investor besar. Sedangkan menurut (Gulati, 2014) crowdfundingdapat dikatakan sebagai representasi dari transformasi sebuah bisnis yang baru atau yang sekarang ini dikenal sebagai startup dan akses pendanaan baru bagi UMKM.

United Nation Development Programme (UNDP) (2017) mengklasifikasikan crowdfunding ke dalam empat model, yaitu:

\section{Equity Crowdfunding}

2. Crowdfundingjenis ini, investor memiliki saham ekuitas pada 
proyek yang dikampanyekan melaluiplatform crowdfunding dan bergantung pada kerangka regulasi.

\section{Donation based Crowdfunding}

4. Para penggalang dana tidak mengharapkan apapun sebagai imbal hasilnya. Crowdfunding ini lahir dari jiwa sosial kemanusiaan atau melalui seni. Biasanya donasi ini untuk membantu korban bencana, kelaparan, pendidikan dan kepentingan umum lainnya. Dalam crowdfunding ini, salah satu yang berperan dalam menarik donatur yaitu kampanye proyek itu sendiri.

\section{Reward Crowdfunding}

6. Dalam crowdfunding ini, para penggalang dana memberikan dananya dengan mengharap imbalan yang dapat berupa hadiah, produk atau pelayanan dari perusahaan start-up bukan berupa pengembalian dana.

\section{Lending/Debt Crowdfunding}

8. Crowfunding pinjaman ini merupakan jenis crowdfunding yang paling cepat pertumbuhannya. Lebih dikenal dengan sebutan Peer to Peer
Lending ( $\mathrm{P} 2 \mathrm{P})$, para penggalang dana crowdfunding ini mengharapkan adanya keuntungan dari dana yang diinvestasikan. Para investor dapat memilih untuk menginvestasikan dananya ke individu atau kepada perusahaan.

$$
\text { Bagi pelaku usaha dan }
$$
UMKM, crowdfunding memiliki keunggulan-keunggulan yang tidak didapat dari lembaga keuanagan tradisional saat mengajukan permodalan. (Mitra, 2012) mengutip pernyataan (Burtch, 2012) bahwa seluruh transaksi online yang diimplementasikan dalam sistem crowdfunding memperlihatkan sebuah sistem yang transparan serta kenyamanan yang lebih terjaga dalam hal pertukaran dana dan kemudahan prosedur bagi para investor maupun peminjam. Selanjutnya, (Belleflemme dan Lambert, 2014) menyatakan hal ini dapat berperan sebagai alat promosi karena mampu menjangkau masyarakat lebih luas. Jika dilihat dari sisi masyarakat luas sebagai konsumen, hal tersebut membuat pilihan terhadap suatu produk 
Rahmawati R, Anju A, Sarrah F. Kesadaran dan Persepsi Usaha..

menjadi lebih bervariasi. Sedangkan dari sisi peminjam, dapat menekan pengeluaran biaya operasional dan biaya promosi.

\section{Islamic Crowdfunding}

Pesatnya perkembangan crowdfunding konvensional saat ini mendorong tumbuhnya crowdfunding berbasis syariah. Hal ini dapat mengakomodir masyarakat yang ingin tetap menjadi pelaku dalam crowdfunding namun dengan skema yang Islami. Apabila dilihat dari teori dan praktiknya, baik crowdfunding maupun keuangan Islam dalam lingkup ekonomi Islam memiliki nilai-nilai dan tujuan yang sama. Keduanya menyajikan sebuah sistem kemitraan, keadilan ditribusi kekayaan dan tolong menolong. Namun, agar crowfunding memenuhi nilai-nilai maslahah haruslah ada ketentuan lain yang disesuaikan baik dari sisi akad maupun objek project yang akan didanai. (Biancone, 2016) berpendapat bahwa baik crowdfunding dan keuangan Islam memiliki konsep yang sama bahwa customer adalah investor. Menurutnya, keduanya berpotensi untuk melakukan investasi bersama- sama dengan return yang tinggi sehingga tercipta pembagian keuntungan yang adil. Hal ini seperti dikatakan oleh (Toha dan Macias, 2014) bahwa crowdfunding dan keuangan Islam cocok secara inheren. Hal ini dikarenakan bahwa secara general, keduanya memiliki karakteristik yang mirip dan pertumbuhannya yang cepat (Hassan dan Dounia, 2013).

Menurut (Marzban dan Asutay, 2014), crowdfunding yang dianggap sesuai dengan nilai-nilai Islam haruslah memiliki kriteriakriteria khusus. Pertama, platform crowdfunding tersebut wajib diatur oleh dewan syariah. Di Indonesia, legalitas tersebut dimiliki oleh Dewan Pengawas Syariah. Kedua, setiap proyek yang menjadi objek investasi harus memiliki tanggung jawab secara sosial bukan kepentingan profit semata. Ketiga, sumber pendapatan platform diperoleh dari sumber yang halal, tidak mengandung riba dan dengan cara yang baik. Hal ini juga menandakan bahwa etika bisnis syariah sangat diperlukan dalam proses operasional platform tersebut. 
Beberapa penelitian terkait hal ini antara lain penelitian oleh (Ghazali dan Yasuoka, 2018) mengenai kesadaran dan persepsi Usaha Kecil Menengah dan Start-Up terhadap instrumen fintech yaitu crowdfunding dan Peer to Peer Lending (P2P). Penelitian ini menunjukkan bahwa saat ini tingkat kesadaran sebagian UKM di Malaysia terhadap pinjaman P2P dan crowdfunding sebagai instrumen pembiayaan alternatif masih kurang. Analisis deskriptis memperlihakan, bahwa mayoritas responden tidak memiiki pengalaman dalam kedua instrument tersebut.

Penelitian ini menggunakan konstruksi survey sebanyak 28 pertanyaan berdasarkan model AIDA (Attention, Interest, Desire, Action) yang dilakukan terhadap 30 responden UKM dan Start-Up di Malaysia. Hasil penelitian ini juga membicarakan bahwa elemen yang paling dipertimbangkan ketika UKM dan start-up memilih jaringan P2P atau crowdfunding sebagai sumber pembiayaan adalah adanya persetujuan pemerintah. Sementara itu, responden juga mengharapkan pengembangan Fintech dapat dipermudah agar dapat menjadi alternatif sumber pembiayaan untuk UKM dan start-up di berbagai sektor. Penelitian lain terkait permasalahan ini yaitu yang dilakukan oleh (Quandah, 2016) mengenai pengaruh perdanaan crowdfunding terhadap kebebasan berinovasi dan nilai kreativitas pengusaha. Sebanyak 200 pelaku usaha di Jordania baik yang pernah mengajukan pembiayaan melalui crowdfunding maupun yang belum pernah melakukanya. Hasil penelitian ini menunjukkan bahwa crowdfunding memiliki dampak yang positif terhadap kewirausahaan yaitu semakin berkembang untuk mendapatkan permodalan bahkan crowdfunding dapat mendorong lahirnya usaha-usaha baru.

\section{METODE PENELITIAN}

Metode yang digunakan dalam penelitian ini adalah analisis kuantitatif deskriptif. Data yang digunakan adalah data primer dari hasil penyebaran kuisioner. Sebanyak 33 orang responden merupakan pelaku Usaha Mikro dan Kecil yang tersebar secara acak di 
Rahmawati R, Anju A, Sarrah F. Kesadaran dan Persepsi Usaha..

Jakarta, Bogor, Depok, Tangerang, dan Bekasi (JABODETABEK).

\section{Konstruksi Kuisioner}

Kuesioner dalam penelitian ini terdiri dari 3 bagian utama, yaitu pertanyaan umum berupa identitas usaha, pertanyaan terkait kesadaran mengenai crowdfunding dan pernyataan-pernyataan terkait persepsi UMK terhadap crowdfunding syariah. Konstruk kuesioner akan dijelaskan pada tabel di bawah ini.

Pertanyaan mengenai skala usaha responden dapat memilih skala mikro atau kecil berdasarkan Undang-Undang Nomor 20 Tahun 2008 mengenai UMKM. UU tersebut menyatakan bahwa usaha mikro yaitu memiliki kekayaan bersih dengan total maksimal Rp. 50.000.000 namun belum termasuk tanah dan bangunan tempat usaha. Selain itu total hasil penjualan tahunannya maksimal sebesar Rp. 300.000.000. Sedangkan usaha kecil yaitu jumlah kekayaan bersih berkisar lebih dari Rp. 50.000 .000 sampai Rp. 500.000.000 dan belum termasuk tanah serta bangunan tempat usaha. Kemudian hasil penjualan usaha kecil yaitu melebihi Rp. 300.000.000 sampai dengan Rp. 2.500.000.000 pertahunnya.

Pertanyaan mengenai sektor usaha didasarkan pada tujuh sektor bisnis UMKM secara umum menurut Bank Indonesia dan Lembaga Pengembangan Perbankan Indonesia (LPPI). Ketujuh sektor bisnis tersebut yaitu perdagangan, industri pengolahan, pertanian, perkebunan, peternakan, perikanan, dan jasa.

Bagian pertanyaan umum, akan diketahui juga frekuensi responden UMK dalam mengajukan permodalan melalui lembaga keuangan tradisional. Selain itu, akan diketahui pula persepsi UMK terhadap sebab yang membuat UMK tidak mengajukan permodalan melalui lembaga keuangan tradisional sebagai pembanding dari data BPS pada grafik sebelumnya.

Variabel kesadaran bertujuan untuk mengetahui sejauh mana para UMK mengetahui tentang crowdfunding syariah khususnya yang berfungsi sebagai sumber permodalan usaha. Sedangkan variabel persepsi, bertujuan untuk mengetahui bagaimana persepsi 
UMK terhadap crowdfunding syariah sebagai alternatif permodalan usaha. Pernyataan-pernyataan yang diberikan kepada UMK dalam variabel ini berdasarkan pada penelitian-penelitian terdahulu.

\section{Tabel 1}

\section{Konstruk Kuisioner}

\section{Pertanyaan Umum Karakteristik} Responden

Q1: Skala Usaha

Q2: Jenis Kelamin Responden

Q3: Usia Responden

Q4: Domisili Responden

Q5: Lama usaha berdiri

Q6: Sektor Usaha

Q7: Apakah pernah mengajukan permodalan untuk usaha anda di lembaga keuangan tradisional (Bank/BPR/BPRS/Koperasi/BMT) ?

Q8: Menurut saya, hal-hal di bawah ini menjadi alasan UMK tidak mengajukan pembiayaan modal usaha melalui lembaga keuangan:

Q8 (a): Belum membutuhkannya

Q8 (b): Usulannya ditolak

Q8 (c): Bunga yang tinggi

Q8 (d): Tidak ada jaminan/agunan

Q8 (e): Tidak tahu prosedurnya

Q8 (f): Prosedur yang sulit dan rumit

\begin{tabular}{|l|}
\hline Kesadaran UMK \\
\hline Q9: Apakah anda pernah \\
mendengar tentang platform \\
website untuk permodalan usaha \\
secara online? \\
Q10: Apakah anda pernah \\
mendengar tentang situs-situs \\
seperti gandengtangan.org, \\
wujudkan.com, kitabisa.com? \\
Q11: Apakah anda pernah \\
mendengar tentang situs-situs \\
seperti ammana.id, kerjasama.com,
\end{tabular}

Beberapa penelitian menjabarkan keuntungan-keuntungan yang tidak didapat ketika mengajukan pembiayaan melalui lembaga keuangan tradisional.

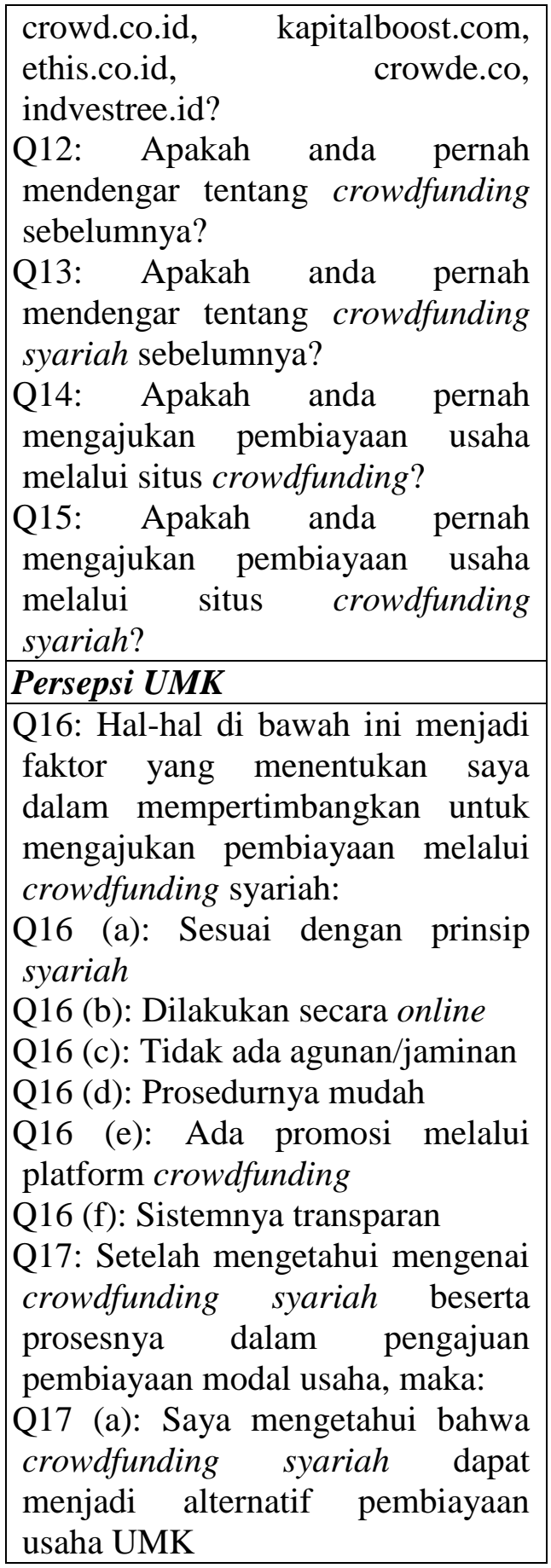

Received: 2019-07-17 | Reviced: 2019-07-18 | Accepted: 2019-07-23

Indexed : Sinta, DOAJ, Garuda, Crossref, Google Scholar | DOI:

https://doi.org/10.29313/amwaluna.v3i2.4798 
Q17 (b): Saya mengetahui bahwa crowdfundingsyariah dapat menjadi akses sumber modal yang efektif

Q17 (c): Menurut saya, penting bagi UMK untuk mengetahui alternatif pembiayaan seperti crowdfunding syariah

Q17 (d): Saya akan mempertimbangkan untuk mengajukan permodalan melalui crowdfunding syariah di waktu yang akan datang

Q17 (e): Saya akan menyarankan

UMK lain untuk mengajukan pembiayaan modal melalui crowdfunding

Sumber: Diolah (2019)

\section{HASIL DAN PEMBAHASAN}

\section{Profil Responden}

Grafik 2

Profil Responden Berdasarkan Gender

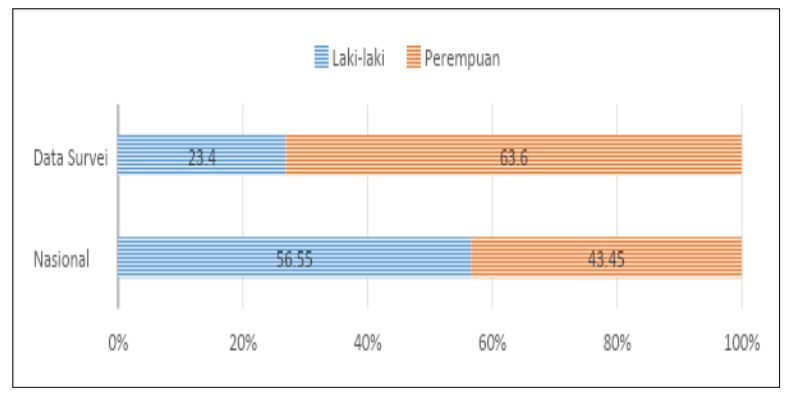

Sumber: Diolah (2019)

Dari 33 pelaku UMK pada penelitian

ini, 21 responden atau sebanyak

63,6\% adalah perempuan dan 12

orang lainnya sebanyak 23,4\%

merupakan laki-laki.
Sedangkan data nasional menurut BPS tahun 2016 (2018), sebanyak $56,55 \%$ persen UMK adalah lakilaki, sedangkan sisanya $43,45 \%$ adalah perempuan. 


\section{Grafik 3}

\section{Profil Responden Berdasarkan Skala Usaha}

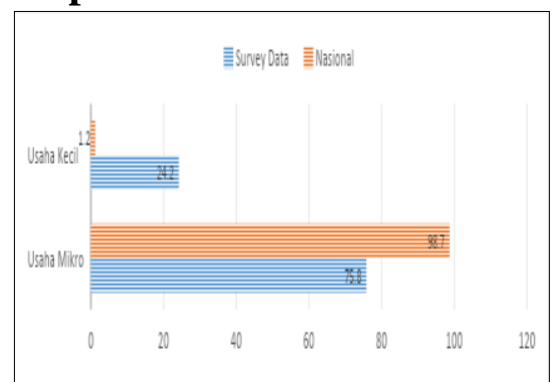

Sumber: Diolah (2019)

Sedangkan dari skala usaha nasional, Kementrian Koperasi dan responden, pada penelitian ini UKM pada tahun 2017 sebanyak terdapat 23 responden atau $75,8 \%$ 62.106.900 pelaku usaha mikro atau termasuk ke dalam usaha mikro dan sekitar $98,7 \%$ dan 757.090 pelaku 10 responden atau $24,2 \%$ merupakan usaha kecil atau hanya sekitar $1,2 \%$ pelaku usaha kecil. Jika dari total UMKM nasional. dibandingkan dengan data skala

\section{Grafik 4}

\section{Profil Responden Berdasarkan Usia}

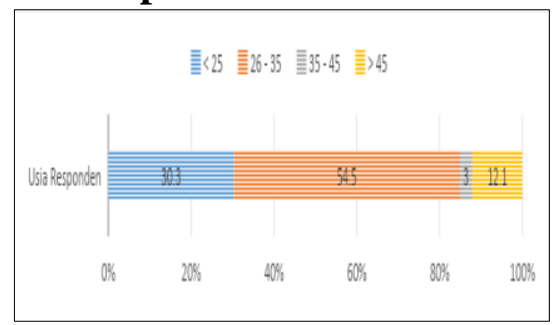

Sumber: Diolah (2019)

Pada penelitian ini, sebanyak 30,3\% responden atau sebanyak 10 orang berusia kurang dari 25 tahun. Jumlah terbesar dimiliki oleh responden berusia 26 sampai dengan 35 tahun yaitu sebanyak 18 orang atau sekitar
$54,5 \%$ dari total responden. Sedangkan responden berusia 36 sampai 45 tahun hanya $3 \%$ atau hanya 1 orang saja. Sisanya sebanyak $12,1 \%$ berusia lebih dari 45 tahun yaitu sebanyak 4 orang. 


\section{Grafik 5}

\section{Profil Responden berdasarkan Wilayah Domisili}

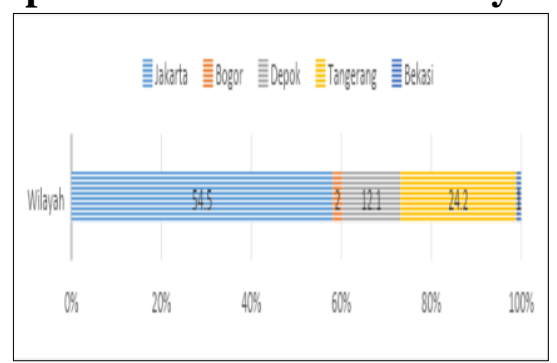

Sumber: Diolah (2019)

Sebanyak $54,5 \%$ responden berasal dari Jakarta yaitu berjumlah 18 orang. Responden berasal dari Bogor hanya $2 \%$ atau sebanyak 2 orang. $12.1 \%$ responden atau sebanyak 4 orang berasal dari Depok dan 8 orang responden berasal dari Tangerang dengan presentase $12,1 \%$. Sisanya sebesar $1 \%$ atau 1 orang berasal dari Bekasi.

\section{Grafik 6}

\section{Profil Responden berdasarkan Sektor Usaha (Persen)}

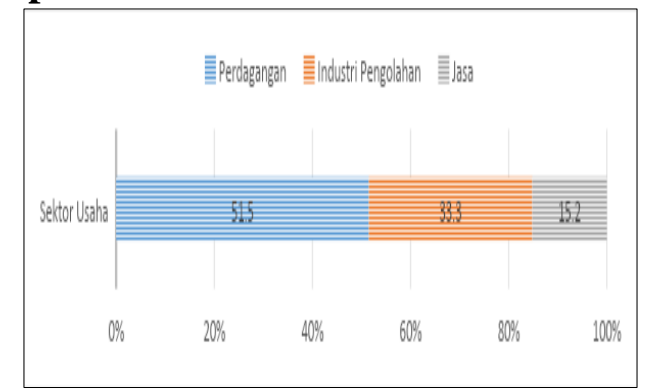

Sumber: Diolah (2019)

Menurut sektor utama usaha, diantaranya adalah pengolahan sebanyak 51,5\% UMK atau 17 orang makanan dan minuman, pakaian, responden bergerak di bidang furniture dan kerajinan tangan. perdagangan, baik eceran maupun Sedangkan sisanya $15,2 \%$ atau grosir. Sebanyak 11 orang atau sebanyak 5 orang yaitu memiliki $33,3 \%$ usaha merupakan dalam usaha di bidang jasa. lingkup industri pengolahan, 


\section{Grafik 7}

Profil Responden Berdasarkan Usia Usaha (Persen)

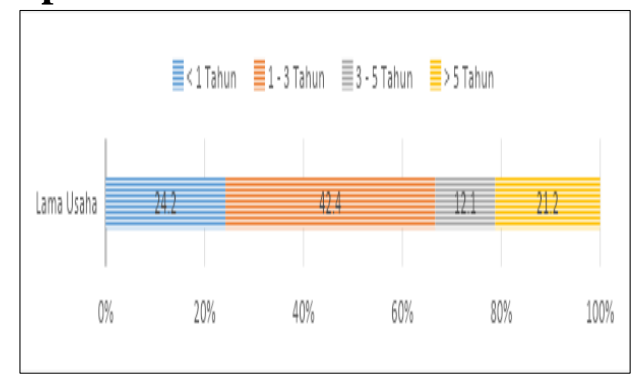

Sumber: Diolah (2019)

Responden pada penelitian ini sebanyak 8 orang yaitu memiliki usaha yang baru saja berjalan kurang dari setahun atau sebanyak 24,2\%. Sebanyak 42,2\% responden atau 14 orang lainnya telah menjalankan usahanya selama sekitar 1 sampai dengan 3 tahun. Responden yang usahanya telah berjalan selama lebih dari 3 tahun sampai dengan 5 tahun yaitu sebanyak $12,1 \%$ atau sejumlah 4 orang responden. Sisanya sebanyak 7 orang responden atau $21,2 \%$ mengaku telah menggeluti usahanya selama lebih dari 5 tahun.
Frekuensi meminjam kepada lembaga keuangan tradisional

Sebelum mengetahui persepsi UMK terhadap lembaga keuangan tradisional dalam hal pengajuan permodalana, UMK ditanya terlebih dahulu mengenai frekuensi pengajuan permodalan. Hasil survei dapat diketahui seperti ditunjukkan oleh grafik 8 di bawah ini. Sedangkan persepsi UMK tentang alasan UMK yang tidak mengajukan permodalan mengacu pada survei yang dilakukan oleh BPS secara nasional (lihat grafik 1). Hasil survei mengenai hal tersebut terlihat pada grafik 9. 


\section{Grafik 8}

Frekuensi UMK Mengajukan Permodalan ke Lembaga Keuangan Tradisional (Persen)

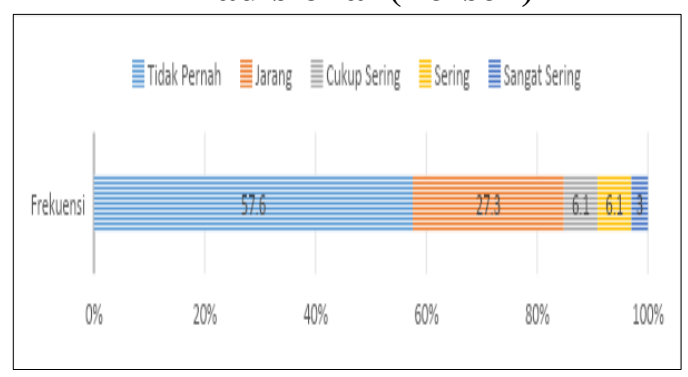

Sumber: Diolah (2019)

Pada penelitian ini juga diketahui memiliki frekuensi cukup sering frekuensi responden dalam hal mengajukan permodalan yaitu 3 pengajuan permodalan usaha ke sampai 5 kali dan frekuensi sangat lembaga keuangan tradisional. sering yaitu lebih dari 7 kali. Lembaga keuangan yang dimaksud Sedangkan responden dengan antara lain yaitu bank atau bank frekuensi jarang yaitu hanya 1 atau 2 syariah, koperasi atau koperasi kali melakukan pengajuan yaitu syariah, BMT dan BPR/BPRS. sebanyak 27,3\% atau 9 orang. Diketahui dari total responden yang Sedangkan mayoritas responden diteliti, hanya 1 responden atau 3\% menyatakan bahwa mereka belum yang pernah mengajukan permodalan pernah melakukan pengajuan dengan frekuensi sering yaitu permodalan, yaitu sebanyak 19 orang sebanyak 6 sampai 7 kali. 2 orang atau 57,6\% dari total responden. responden atau $6,1 \%$ masing-masing

\section{Grafik 9}

Alasan UMK Tidak Mengajukan Permodalan di Lembaga Keuangan (Orang)

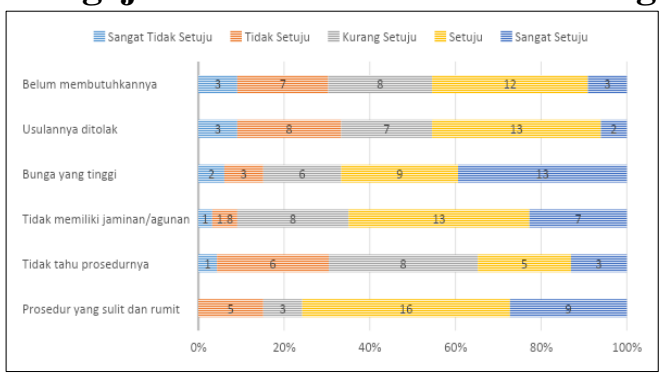

Sumber: Diolah (2019)

Grafik di atas menunjukkan bahwa responden UMK atau sekitar $36,4 \%$ mayoritas UMKyaitu sebesar 12 setuju bahwa memang belum 
membutuhkan untuk mengajukan permodalan ke lembaga keuangan. Mayoritas UMK juga berpendapat setuju pada alasan usulan yang ditolak dank arena tidak memiliki agunan. UMK yang menyatakan masing-masing sebanyak 13 orang atau sekitar $39,4 \%$. Pernyataan mayoritas setuju lainnya yaitu sebesar $48,4 \%$ atau sekitar 16 orang untuk alasan sulit dan rumitnya prosedur UMK dalam pengajuan modal.

Bunga tinggi yang dibebankan kepada UMK selaku peminjam dana menjadi satu-satunya alasan dengan tingkat "sangat setuju" paling tingggi yaitu sekitar 39,3\% atau sebanyak 13 responden UMK. Sedangkan untuk alasan ketidaktahuan prosedur, mayoritas UMK justru menjawab "kurang setuju" yaitu yang dinyatakan oleh 8 orang UMK atau hanya sekitar $24,2 \%$ dari total responden.

\section{Kesadaran terhadap crowdfunding syariah}

Variabel ini bertujuan untuk mengetahui sejauh mana pelaku UMK mengetahui dan menyadari akan hadirnya sebuah konsep crowdfunding syariah saat ini dan manfaat yang didapat oleh pelaku usaha.

Grafik 10

Kesadaran UMK terhadap Situs Populer Crowdfunding (Orang)

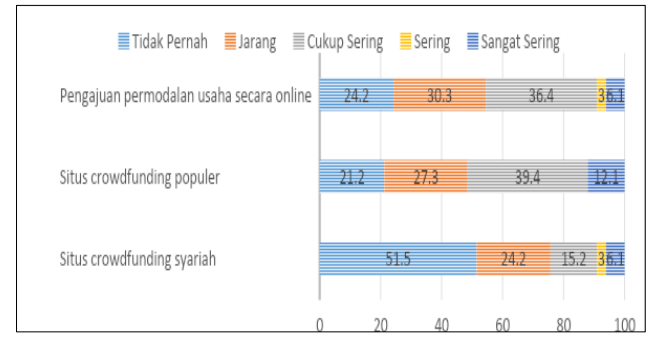

Sumber: Diolah (2019)

Pada grafik 10, menunjukkan bahwa melalui website. Hal ini dinyatakan mayoritas UMK responden sudah oleh sekitar 36,4\% UMK atau cukup familiar mendengar tentang adanya sebuah sistem pengajuan sebanyak 12 responden UMK. Akan permodalan usaha secara online tetapi, masih ada $24,2 \%$ UMK atau Received: 2019-07-17 | Reviced: 2019-07-18 | Accepted: 2019-07-23 Indexed : Sinta, DOAJ, Garuda, Crossref, Google Scholar | DOI: https://doi.org/10.29313/amwaluna.v3i2.4798 
Rahmawati R, Anju A, Sarrah F. Kesadaran dan Persepsi Usaha..

mendengar sama sekali mengenai hal ini.

Sedangkan, saat disebutkan beberapa situs crowdfunding popular, mayoritas UMK baru menyadari bahwa situs-situs tersebut merupakan sebuah bentuk inovasi yang disebut dengan crowdfunding. Hal ini terbukti dengan jumlah sekitar $39,4 \%$ UMK atau sebanyak 13 orang mengaku cukup sering mendengar dan $27,3 \%$ atau 9 responden UMK mengaku pernah sesekali mendengarnya.

Akan tetapi, saat disebutkan platform crowdfudning syariah, masih banyak yang belum pernah mendengarnya sama sekali. Hal ini terbukti sebanyak 17 orang UMK atau sekitar $51,5 \%$ dari total responden. Hal ini membuktikkan bahwa crowdfunding syariah masih belum terlihat eksistensinya di kalangan pelaku UMK.

Grafik 11

Kesadaran UMK terhadap Konsep Crowdfunding Syariah (Orang)

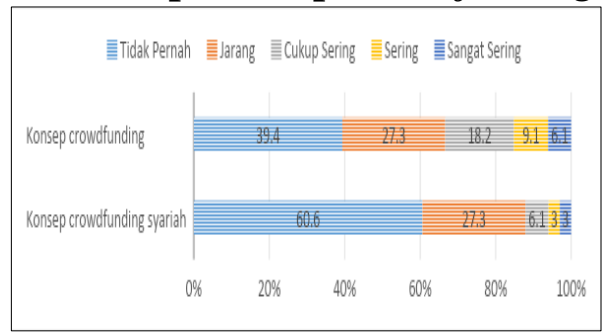

Sumber: Diolah (2019)

Pada grafik 11 di atas, menunjukkan keberagaman reaksi dari responden UMK. Meskipun mayoritas belum pernah mendengar dan mengetahui konsep crowdfunding yang dinyatakan oleh 13 UMK atau sekitar $39,4 \%$, namun responden lainnya setidaknya pernah dan beberapa orang pun cukup sering mendengan istilah crowdfunding. Hal ini berbanding terbalik dengan kesadaran UMK atas konsep crowdfunding syariah. Sebanyak 20 UMK atau sekitar $60,6 \%$ menyatakan belum pernah sama sekali mendengar tentang konsep ini. 


\section{Grafik 12 \\ Frekuensi UMK Mengajukan Permodalan UMK Melalui Platform} Crowdfunding (Persen)

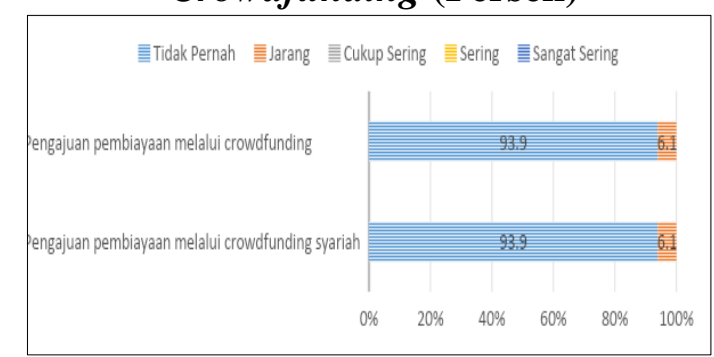

Sumber: Diolah (2019)

Dari grafik yang ditampilkan di atas,

kesadaran UMK terhadap crowdfunding dan crowdfunding syariah khususnya untuk permodalan usaha masih sangat minim. UMK baru menyadari konsep crowdfunding ketika disebutkan platform-platform popular di kalangan masyarakat seperti kitabisa.com, meski kitabisa.com

\section{Persepsi terhadap crowdfunding} syariah

Pada variabel persepsi UMK, grafik dibagi menjadi dua. Pertama, yaitu grafik 10 menunujukkan dua hal yang bisa saja UMK dapatkan jika melakukan pengajuan permodalan kepada lembaga keuangan cenderung bersifat sosial dan memberdayakan dan bukan untuk proyek profit. Meskipun begitu, terdapat masing-masing 2 orang responden atau $6,1 \%$ pernah mengajukan pembiayaan usaha melalui crowdfunding, baik konvensional maupun dengan skema syariah

tradisional. Sedangkan grafik kedua adalah fasilitas yang UMK dapatkan apabila mengajukan pembiayaan modal usaha melalui platform crowdfunding syariah. Dalam hal ini, penulis berasumsi bahwa sudah cukup banyak lembaga keuangan yang memberikan kemudahan prosedur kepada UMK. 


\section{Grafik 10}

\section{Persepsi UMK terhadap Crowfunding Syariah Berdasarkan Prinsip Syariah} dan Kemudahan Prosedur (Orang)

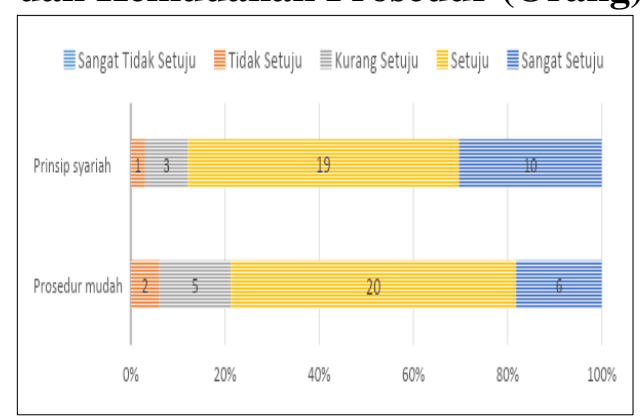

Sumber: Diolah (2019)

Grafik 10 menunjukkan bahwa setelah UMK mengetahui tentang konsep dan alur pengajuan pembiayaan modal usaha melalui crowdfunding syariah, sebanyak 19 responden atau sekitar $57,6 \%$ menyatakan bahwa kesesuaian terhadap prinsip syariah menjadi salah satu alasan persetujuan UMK dalam crowdfunding syariah. Selain itu, kemudahan prosedur yang ditawarkan oleh crowdfunding syariah mendapat opini "setuju" dari 20 responden atau sekitar 60,6\%.

\section{Grafik 11}

Persepsi UMK terhadap Crowfunding Syariah Berdasarkan Keuntungan dari Konsep Crowdfunding Syariah (Orang)

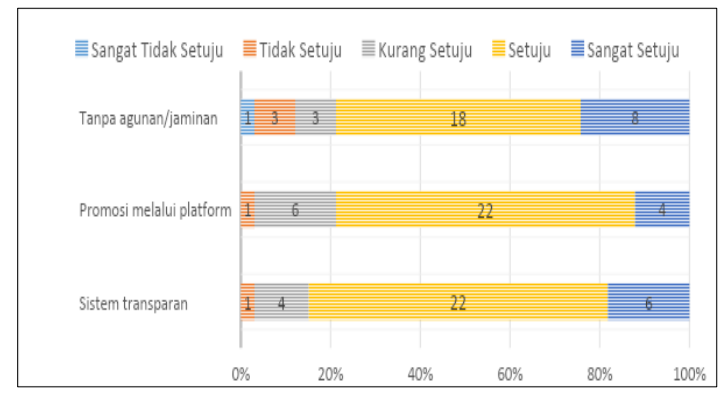

Sumber: Diolah (2019)

Dari hasil survei diketahui bahwa mayoritas UMK setuju bahwa tanpa adanya jaminan menjadi hal yang dapat dipertimbangkan UMK untuk menggunakan crowdfunding syariah. UMK yang menyatakan setuju yaitu 
sebanyak 18 orang atau sekitar Minat terhadap Crowdfunding $54.5 \%$. Dua keuntungan lainnya Syariah

yaitu adanya promosi melalui platform dan sistem yang transparan antara aktor dalam crowdfunding juga menjadi pertimbangan mayoritas UMK. Mayoritas UMK menyatakan setuju masing-masing sebanyak 22 orang atau sekitar $66,66 \%$.

Grafik 12 sampai dengan grafik 14 menunjukkan seberapa besar keinginan responden untuk mengetahui lebih lanjut mengenai crowdfunding syariah dan mempertimbangkannya untuk menggunakannya di kemudian hari.

Grafik 12

Minat UMK terhadap Crowdfunding Syariah Sebagai Sumber Modal Usaha (Orang)

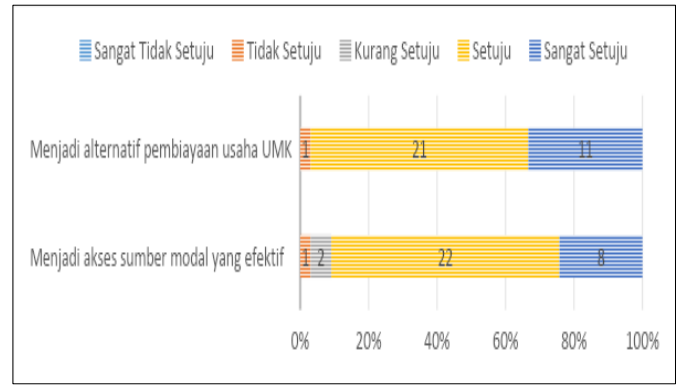

Sumber: Diolah (2019)

Grafik 12 menunjukkan bahwa UMK efektif. Masing-masing sebanyak 21 setuju jika crowdfunding syariah responden atau $63,7 \%$ dan 22 dapat dikatakan sebagai alternatif responden atau sebesar $66,66 \%$ pembiayaan modal usaha dan mengaku setuju akan pernyataan ini. menjadi sumber permodalan yang

\section{Grafik 13}

\section{Minat UMK untuk Memahami Crowdfunding Syariah (Orang)}

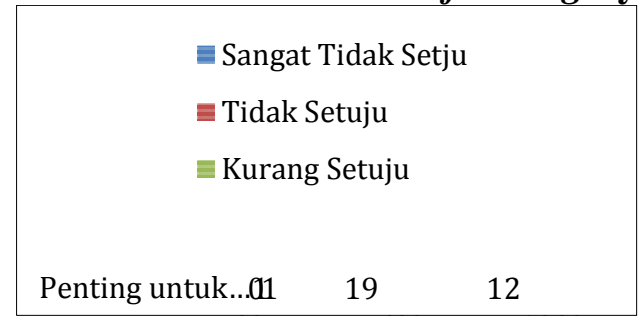

Sumber: Diolah (2019) 
Rahmawati R, Anju A, Sarrah F. Kesadaran dan Persepsi Usaha..

Sedangkan grafik 13, mayoritas UMK dianggap dapat menjadi alternatif menyatakan bahwa crowdfunding pilihan selain lembaga keuangan syariah penting untuk diketahui para tradisional lainnya jika memerlukan pelaku UMK. Crowdfunding syariah tambahan modal usaha.

\section{Grafik 14}

\section{Minat UMK untuk Menggunakan Crowdfunding Syariah di Masa Depan} (Orang)

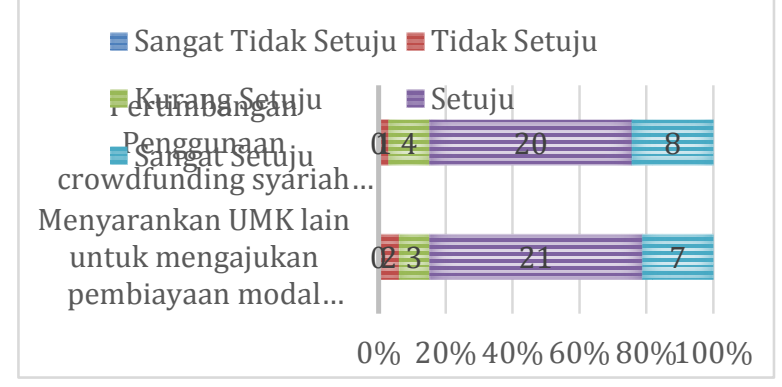

Sumber: Diolah (2019)

Sedangkan pada grafik 14 terhadap eksistensi crowdfunding menunjukkan bahwa mayoritas UMK akan mempertimbangkan untuk menggunakan crowdfunding syariah dalam permasalahan modal usaha yaitu sebanyak 20 orang atau sekitar 60,6\%. Sekitar 63,6\% atau sebanyak 21 responden juga bersedia untuk menyarankan pelaku UMK lain untuk menggunakan crowdfunding syariah jika menemui kendala permodalan usaha.

\section{SIMPULAN}

Berdasarkan hasil dari data primer yang dikumpulkan, dapat disimpulkan bahwa kesadaran UM syariah masih rendah. Hal ini salah satunya disebabkan karena kurangnya sosialisasi baik dari platform crowdfunding syariah maupun pemerintah. Seharusnya, dengan munculnya banyak alternative permodalan bagi UMKM, kendala permodalan beserta kendala lain yang mengikutinya dapat diminimalisir. Selain itu, kurangnya literasi UMK terhadap keuangan juga dapat menjadi penyebab kurang terdistribusinya informasi mengenai crowdfunding syariah.

Akan tetapi, persepsi yang ditunjukkan oleh UMK terhadap 
crowdfunding syariah sebagai alternatif pembiayaan usaha sangatlah baik. Hal ini dapat menjadi modal semakin berkembangnya platform crowdfunding di Indonesia. Atas dasar ini, pemerintah dan pihak platform dapat lebih giat mensosialisasikan lebih luas lagi.

Pemerintah juga perlu secepatnya mengeluarkan aturan terkait hal ini yang dihususkan untuk UMKM. Peraturan mengenai Equity Crowdfunding dianggap belum menyentuh tatanan UMKM khususnya pengusaha mikro dan kecil.

\section{DAFTAR PUSTAKA}

Achsien, I. H, \& Purnamasari, D. L. (2016). Islamic Crowdfunding as The Next Financial Innovation in Islamic Finance: Potential and Anticipated Regulation in Indonesia. European Journal of Islamic Finance, Nomor 5, 2016.

Bank Indonesia dan Lembaga Pengembangan Perbankan Indonesia (LPPI). (2015).
Profil Bisnis Usaha Mikro, Kecil dan Menengah (UMKM).

Belleflamme, P, \& Lambert, T. (2014). Crowdfunding: Some Empirical Findings and Microeconomic Underpinnings. Louvain School of Management Research Institute.

Cambridge Centre for Academic Finance. (2018). The $3^{\text {rd }}$ Asia Pasific Region Alternative Finance Industry Report. Judge Business School, University of Cambridge.

Ghazali, N.H., Yasuoka, T. Awareness and Perception Analysis of Small Medium Enterprise and Start-up Towards FinTech Instruments - Crowdfunding and Peer-to-Peer Lending in Malaysia. International Journal of Finance and Banking Research. Vol. 4, No. 1, 2018, pp. 13-24. 
Rahmawati R, Anju A, Sarrah F. Kesadaran dan Persepsi Usaha..

Hassan, B., \& Dounia, B. (2013).

Kasali, R. (2017).

Perceiving Success among

Disruption. Jakarta:

Shariah Compliant

Gramedia Pustaka Utama.

Crowdfunding Social

Entrepreneurs. Revue de

Gestion et d'Economie, Vol.

6(3), pg. 264-293.

Hidajat, T., Primiana, I., Nidar, S.,

\& Febrian, E. (2016).

Crowdfunding: Financial

Service for Unserved

Crowds in Indonesia.

International Conference of

Integrated Microfinance

Management, Padjajaran

University, Bandung, pg. 109-115.

Ibrahim, N., \& Verliyantina.

(2012). The Model of

Crowdfunding to Support

Small and Micro Businesses

in Indonesia Through a

Web-based platform.

International Conference on

Small and Medium

Enterprises Development

(ICSMED) 2012, Kuta Bali,

pg. 390-397.

Mitra, D. (2012). The Role of Crowdfunding in Entrepreneurial Finance. Delhi Business Review, Vol 13, No. 2.

Quandah, E. (2016). The Effect of Crowdfunding on Entrepreneurship Exploratory Study from the Perspective of Entrepreneurs in Business Incubators in Jordan. (Tesis Magister, Fakultas Bisnis, Middle East University). 
United Nation Development

Program (UNDP). (2017).

Crowdfunding. Financing

Solution for Sustainable

Development.

World Bank. (2013).

Crowdfunding's Potential for the Developing World.

Washington, DC: Finance

and Private Sector

Development Department,

World Bank 